\title{
The Role of Public Menagmentit, in the Interest of Increasing the Efficiency of Governance, (with Special Focus on Kosovo)
}

\author{
Driton Fetahu \\ PhD. (Candidate in European University of Tirana) \\ Tax inspector, Ministry of finance, Regional office in Prizren, Kosovo. \\ e-mail:driton_fetahu@hotmail.com, +37744/337-667
}

\section{Doi:10.5901/mjss.2013.v4n9p735}

\begin{abstract}
The paper deals with distinct nature of institutions in the process of economic development, impact they have on organization and functioning of public sector. Paper deals with introduction and functioning of management practice in public sector, role of economic factors, and impact of socio-political environment of changes in this sector, how they manage in public sector. The Public Sector is the principal actor in macro socio-economic policy making infrastructure and an architect of an enabling environment for national development. Public Sector management covers such aspects of management as productivity management, and management of human, financial and other resources. It involves an array of activities ranging from planning, formulation and implementation of policies, programmers and projects for the delivery of goods and services to the nation through a number of government and quasi-government institutional arrangements. Consequently, it is imperative that the structures, policies and operations of the Public Sector respond adequately to the socioeconomic needs of the nation, as articulated in the Vision 2016, and to global challenges. This implies that the quality of the Public Sector management is essential to the fulfillment of the theme of the National Development Plan 9: 'Towards Realization of the Vision 2016: Sustainable and Diversified Development through Competitiveness in the Global Market'.
\end{abstract}

\section{The Role of Institutions}

Nobel Prize winner for D. North's institutions have all the formal and informal rules that govern human relations, in narrow sense as the Organization, procedures, regulatory bodies, and in the wider property relations and the rule of law.

The quality of institutions is assessed in three ways:

First, the quality of government-political rights, corruption, public sector efficiency, regulation of monopolies; Second, the legal protection of private property, and Third, the limitations of the political elite.

Example of measuring the quality of institutions is an aggregate index of the rule which includes six groups of factors. Index includes the following elements:

1. Accountability: the extent to which citizens elect the government, with civil rights, the degree of freedom of the press;

2. Political stability and absence of violence: the degree of removability normal parliamentary government, unlike violent and unconstitutional actions;

3. Government effectiveness: the quality of public services offered by the government, competence and accountability of the public about political administration;

4. Degree of regulation: the relative absence of state control and monopoly of all possible markets - goods, capital, labor, information;

5. The rule of law: the protection of people and property from arbitrary, fraud, violent acts, effectively and independently the judiciary;

6. Freedom from looting: the reduction of corruption and misuse of public power in personal gain.

Good institutions have three characteristics:

First, establish and protect property rights in the company;

Second, restricting all possible elite seeking to expropriate someone's income or assets, and

Third, to the extent possible provide equal opportunities for the general population in the field employment, social security and human rights.

Institutions may be different in terms of the impact on economic development:

- Market-made institutions establish and protect property rights, without which there is no market, and; 
- Market-regulating institutions dealing with regulation, externalities, economies of scale, imperfect Information;

- Market-stabilizing institutions reduce macroeconomic volatility and financial crisis, and

- Marketing legitimating institutions provide social protection, health and pension insurance.

The Public Sector is the principal actor in macro socio-economic policy making infrastructure and an architect of an enabling environment for national development. Public Sector management covers such aspects of management as productivity management, and management of human, financial and other resources. It involves an array of activities ranging from planning, formulation and implementation of policies, programmers and projects for the delivery of goods and services to the nation through a number of government and quasi-government institutional arrangements.

Consequently, it is imperative that the structures, policies and operations of the Public Sector respond adequately to the socioeconomic needs of the nation, as articulated in the Vision 2016, and to global challenges. This implies that the quality of the Public Sector management is essential to the fulfillment of the theme of the National Development Plan 9: 'Towards Realization of the Vision 2016: Sustainable and Diversified Development through Competitiveness in the Global Market.

The Directorate of Public Service Management is mandated to provide the overall policy framework in human resource and productivity management practices. This chapter will, therefore, restrict its discussion of the role of the Directorate of Public Service Management in the management of the Public Sector to the areas of human resource and productivity management.

Human resource and productivity management policies and practices are to be used in the Public Sector for effective management of the human capital and other resources required delivering the National Development Plan goals, and ultimately achieving the national aspirations as enshrined in the Vision 2016. The extent to which the goals of the National Development Plan 9, and consequently those of the Vision 2016, are achieved is dependent on how effectively the human and other resources will be applied to the delivery of the planned programmers. It is, therefore, necessary that the envisaged Public Sector management policies and strategies be succinctly spelt out in the National Development Plan 9.

The implementation of the human resource management policies and other management practices in the Public Sector, developed within the macro policy framework provided by the Directorate of Public Service Management, are done through institutional arrangements with specific focus and clientele. This is intended to cater for the special needs of the components of the Public Sector and eventually catalyze the enablement of business environment for national development.

\section{Management in the public sector.}

Ethics state public service gave way to today place the management of the public sector, the public good in this area become economic goods, the welfare state "becomes, the state of entrepreneurship." Managerial philosophy the public sector in particular has changed the position of the local authorities towards greater fragmentation and pluralism, abandonment of secured and largely free of public services, the introduction of competition, moving focus from service delivery to ensure minimal prerequisites, the principle of payment and receipt of services, greater consumer choice and greater managerial freedom and initiative in this sector. The drivers of these changes were changes in the environment the structure of the economy, public perceptions of the public sector, the growing financial restrictions and the rise of monetarist orthodoxy.

Deletes the traditional diversity of the sector. [4, p. 70]

Table 1. Model of public-private

\begin{tabular}{|c|c|}
\hline Private sector model & Model of the public sector \\
\hline Individual choice in the market & Collective Choice community \\
\hline Demand and prices & The need for resources \\
\hline Inaccessible for private action & Openness zaq public action \\
\hline appreciation market & Recognition of the need \\
\hline Search for satisfying market & Search for justice \\
\hline consumer sovereignty & Consumer sovereignty of citizens \\
\hline Competition as a market instrument & Collective action as an instrument of \\
& \\
community
\end{tabular}


The introduction of market principles and expose the public sector responsibilities are not carried over through a political process, but also through the market, all actors in the public sector are no longer solely responsible for compliance procedures, but also for the results. Using the model of a private sector managers are responsible stakeholders, where the results are clearly measurable accountability in the public sector, where the results are more complex, and the network of stakeholders dispersed responsibilities over the basic principle of a democratic parliamentary control.

Table 2. types of liability

\begin{tabular}{|c|c|c|c|c|c|c|}
\hline \multicolumn{9}{|c|}{ Responsibility } \\
\hline Who & $\begin{array}{c}\text { According to } \\
\text { the public }\end{array}$ & Parliament & Manager & Legal & Professional & Market \\
\hline Where & publics & Parliament & stakeholders & courts & $\begin{array}{c}\text { Authorized } \\
\text { persons }\end{array}$ & consumers \\
\hline WHY & Results for & Efficiency & $\begin{array}{c}\text { Efficiency, } \\
\text { effectiveness } \\
\text { results }\end{array}$ & legality & $\begin{array}{c}\text { processes, } \\
\text { behavior }\end{array}$ & For result \\
\hline HOW & Elections & $\begin{array}{c}\text { Parliamentary } \\
\text { of committees } \\
\text { and body }\end{array}$ & $\begin{array}{c}\text { indices } \\
\text { performance }\end{array}$ & $\begin{array}{c}\text { Legal acts of } \\
\text { evaluation }\end{array}$ & $\begin{array}{c}\text { professional } \\
\text { association }\end{array}$ & $\begin{array}{c}\text { market } \\
\text { power }\end{array}$ \\
\hline
\end{tabular}

The introduction of management philosophy public sector includes ten principles [4, p. 100, 101]

1. government must be a catalyst for the introduction of new organizations to provide services;

2. citizens must have the right to control the bureaucrats are transferred to the community;

3. governments should encourage competition, service providers,

4. governments should follow the mission, not rules and regulations;

5. the results of government should be judged by their performance, rather than inputs;

6. the focus should be citizens, consumers of services, not bureaucracy;

7. governments and the public sector need to become a company that earns, not only wasting money,

8. The government needs to be proactive, not reactive, to prevent rather than treat problems

9. The government should be decentralized and to encourage participatory management;

10. The Market mechanisms must take precedence in relation to bureaucratic mechanisms.

R. M. Kanter has defined this as' post-entrepreneurship "[4, p. 104, 105]

Table 3. Model of post-entrepreneurship

\begin{tabular}{|l|l|l|}
\hline & Bureaucracy & POST ENTREPRENEURSHIP \\
\hline organization & On the position and status & $\begin{array}{l}\text { Focused on the individual, authority based } \\
\text { on knowledge }\end{array}$ \\
\hline tasks & Repetition and routine & Creativity, creativity and strive innovation \\
\hline orientation & Rules & The results \\
\hline rewarding & Status & Results and creating value \\
\hline informing & The formal structure, information constraints & Communication and Coalitions \\
\hline Style & $\begin{array}{l}\text { The mandate of decision-roundedness } \\
\text { Responsibility }\end{array}$ & development network \\
\hline direction & Towards Ownership and Control & Towards change and innovation \\
\hline
\end{tabular}

The contribution of managerial philosophy in the public sector is reflected in the following:

1. orientation of empowerment and personal responsibility, not hierarchies decision;

2. emphases on quality, not quantity;

3. focus on users rather than the service provider;

4. emphases on results, not internal procedures;

5. orientation, contractual and market relations, and not professional grade;

6. focus on innovation and diversification, rather than stability and conformity. (p. 105). 
To this end, the British, the Local Government Management Board "in 1996, Established the following general principles having organized local government:

1. smaller management teams in corporations;

2. reliance on specialists in the decision-In order to balance the gains and costs of such an approach was necessary: improve teamwork, dedication work; strengthen communication, transparency and openness, introduce constant quality training; anticipate further time for monitoring and evaluation; increase accountability, introduce management information systems; establish climate of trust and unity of the management team.

Mr. Boyne singled out in 1991. Three possible models of organization of local government [4, p. 132]

The central values organization in the public sector must be: the user first, service quality, staff development, inventers, value for money, flexibility, achieving the set goals, high performance.

Such organization must be 1) Responsible, 2) directed toward the user, and 3) efficient, and all employees must be guided by the principles of professionalism, responsiveness, initiative, determination and entrepreneurship. In order to Create and maintain such organization must be acknowledged environmental challenges - the interests of politicians and key Stakeholders, the requirements of people in the local community, the changes cannot be create overnight, but gradually need to change the culture organization making process;

3. decentralization and the introduction of multifunction organization;

4. organizing legal body that will provide principles, value for money 'and' quality of service ';

5. partnerships and alliances with various organizations.

One possible model to meet these principles is the introduction, organization directly service "(, which is based on a functional decentralization).

Advantages:

- Large enough to recruit competent managers;

- Large enough to affect the realization of its objectives;

- Economies of scale;

- Flexibility to support staff;

- Facilitate the identification and allocation of costs of direct services;

- Facilitate the allocation of resources;

Disadvantages:

- Overriding importance in the affairs of local government;

- Duplication of functions and people;

- The introduction of a new organization disturbs the existing structure;

- Difficulties in recruiting managers;

- Difficult coordination dispersed and separate functions.

In order to balance the gains and costs of such an approach was necessary: improve teamwork, dedication work; strengthen communication, transparency and openness, introduce constant quality training; anticipate further time for monitoring and evaluation; increase accountability, introduce management information systems; establish climate of trust and unity of the management team.

Mr. Boyne singled out in 1991. Three possible models of organization of local government [4, p. 132]

The central values organization in the public sector must be: the user first, service quality, staff development, innovations, value for money, flexibility, achieving the set goals, high performance.

Such organization must be 1) Responsible, 2) directed toward the user, and 3) efficient, and all employees must be guided by the principles of professionalism, responsiveness, initiative, determination and entrepreneurship. In order to create and maintain such organization must be acknowledged environmental challenges - the interests of politicians and key stakeholders, the requirements of people in the local community, the changes cannot be applicator overnight, but gradually

Necessary to change the culture organization.

Table 4. Models of organization of local government

\begin{tabular}{|c|c|c|c|}
\hline & Market & Services Provided & Participary \\
\hline Accent & Utility company & $\begin{array}{c}\text { Provision } \\
\text { direct services }\end{array}$ & The local community \\
\hline Culture & Competitive & Reactive & Proactive \\
\hline \multicolumn{3}{|c}{738}
\end{tabular}




\begin{tabular}{|c|c|c|c|}
\hline Strategic Planning & $\begin{array}{c}\text { Parameters defended } \\
\text { from market } \\
\end{array}$ & $\begin{array}{l}\text { The scope and } \\
\text { priorities by services }\end{array}$ & $\begin{array}{l}\text { Response to requests from } \\
\text { the community }\end{array}$ \\
\hline $\begin{array}{l}\text { The basis for the } \\
\text { provision of service }\end{array}$ & Mixed economy & Professionalism & $\begin{array}{l}\text { Diversity in relation to the } \\
\text { requirements }\end{array}$ \\
\hline $\begin{array}{c}\text { internal } \\
\text { organization }\end{array}$ & Contractive relations & service sector & $\begin{array}{l}\text { matrix, decentralized } \\
\text { and organization }\end{array}$ \\
\hline Responsibility & Mutual responsibility & Selected Committees & citizens in the local community \\
\hline $\begin{array}{l}\text { Relations with other } \\
\text { organizations }\end{array}$ & Through negotiations & $\begin{array}{l}\text { Professional } \\
\text { Autonomy }\end{array}$ & $\begin{array}{l}\text { Dispersed in accordance with } \\
\text { local needs }\end{array}$ \\
\hline
\end{tabular}

To change must be made to meet the following requirements [4, p. 264]

Efficiency: efficient spending of taxpayers' money;

Cost: the lowest possible cost;

Natural environment: environment;

Effectiveness: the impact of the public sector as a whole has to be positive;

Evaluation: The public sector needs to be exposed to assessment and accountability;

Ethics: must establish and maintain standards of behavior;

Markets: the public sector must respond to the demands of the citizens who are the consumers of services.

Change Management includes: [4, p. 272]

Table 5. Changes in the public sector

\begin{tabular}{|l|l|}
\hline TASK & ACTIVITIES \\
\hline Establishment of dynamic change & 1 Provide support key stakeholders \\
& 2 Leaders should create support for changes \\
& 3 Emphasize the importance of changes \\
& 4 Build stability to minimize risk and uncertainty \\
\hline Motivation for change & 5 Dissatisfaction with the current state as a reason for change \\
& 6 Motivation to participate in the changes \\
& 7 Rewarding to support changes \\
& 8 Predict the time to break with the the status quo \\
\hline Manage with changes & 9 Development and transfer of a clear vision of \\
& changes \\
& 10th Changes must cover the entire organization \\
& 11th Build feedback mechanisms \\
\hline
\end{tabular}

\section{Conclusions}

Resistance to change can be influenced by several factors: insufficient resources and time; non identification Problems; lack of coordination; insufficient knowledge turbulent environment; lack of leadership, public Objectives, lack of communication.

A survey was in 1997. Conducted by Public Management Foundation, which polled 1,000 people in four British counties showed the following:,, very satisfied "with their education, $73 \%$ of respondents, with Health, $72 \%$, and $56 \%$ of local authorities. The conclusion is that the degree of satisfaction with the higher than the Politicians and shows that citizen, not politicians have to be a crucial factor in the assessment of the public sector and providing public services. [3] Reform of the public sector in our country will have to provide answers to the following dilemma:

1. centralization - decentralization;

2. control - management initiatives;

3. safeties of employees - evaluation by the user.

\section{References}

Institutions and Economic Development, Finance and Development, br. 2, 2003.

North, D., Institutions, Institutional Change and Economic Performance, CUP, 1990.

Public Management Foundation, London, 1997.

Rose, A., Public Sector Management, Prentice Hall - Financial times, 2003. 